\title{
THE EFFECTS OF ANITRANSPIRANT DI-1-P-MENTHENE ON SOME PHYSIOLOGICAL TRAITS OF STRAWBERRY
}

\author{
Grzegorz Mikiciuk', Małgorzata Mikiciuk², Piotr Ptak²
}

1 Department of Horticulture, Faculty of Environmental Management and Agriculture, West Pomeranian University of Technology in Szczecin, Słowackiego 17 Str., 71-434 Szczecin, Poland, e-mail: grzegorz.mikiciuk@ zut.edu.pl

2 Department of Plant Physiology and Biochemistry, Faculty of Environmental Management and Agriculture, West Pomeranian University of Technology in Szczecin, Słowackiego 17 Str., 71-434 Szczecin, Poland, e-mail: malgorzata.mikiciuk@zut.edu.pl

Received: 2015.06.06 Accepted: 2015.08.31 Published: 2015.10 .01

\begin{abstract}
Strawberry is a species sensitive to water shortages, especially during fruit growth and ripening. One method of limiting water loss in plant production involves the use of antitranspirants, which reduce plant transpiration. One method of limiting water loss in plant production involves the use of antitranspirants, which reduce plant transpiration. One of substances used for this purpose is, amongst others, natural terpene polymer - di-1-p-menthene (pinolene). Research on the influence of a pinolene-containing antitranspirant (with the commercial name of Vapor Gard) on gas exchange parameters (intensity of net $\mathrm{CO}_{2}$ assimilation, intensity of transpiration, stomatal conductance for water, substomatal $\mathrm{CO}_{2}$ concentration), the water balance and the content of assimilation pigments (chlorophyll "a", "b", total chlorophyll, carotenoids) in the leaves of the cv. 'Salsa' strawberry was conducted in the years 2009-2010. The antitranspirant was used once at a concentration of $0.75 \%$ before flowering. The measurements were performed four times: before flowering (1st measurement date), when the plants were in full flowering (2nd measurement date), in the middle of the harvest season (3rd measurement date) and after the end of the harvest season (4th measurement date). Foliar application of the Vapor Gard antitranspirant decreases the intensity of strawberry transpiration without changing the $\mathrm{CO}_{2}$ assimilation activity. Plants sprayed with the tested preparation were characterised by a higher relative water content (RWC) in leaves and a higher value of the photosynthetic index of water use efficiency (WUE). The antitranspirant did not influence the content of assimilation pigments in strawberry leaves. The values of the determined physiological features depended on the measurement date (developmental stage) of the tested strawberry cultivar.
\end{abstract}

Keywords: strawberry, pinolene, Vapor Gard, gas exchange, assimilation pigments.

\section{INTRODUCTION}

Strawberry is a species sensitive to water shortages, especially during fruit growth and ripening. Reduced availability of water induces physiological and biochemical changes in all organs of the plant. Limitation of gas exchange can reduce assimilation of carbon dioxide, which, as a result, limits plant growth and development. Strawberry sensitivity to drought results from the disproportion between a relatively high mass and surface area of the above-ground part of the plant with a high water content in fruits and a shallow and not very extensive root system [Klamkowski and Treder, 2006, 2008]. Limited water resources necessitate more and more rational use of water for irrigation and searching for new fruit production technologies, which reduce water consumption. One method of limiting water loss in plant production involves the use of antitranspirants, which reduce plant transpiration [Latocha et al., 2009; Masoud, 2012; Abdel-Fattah, 2013]. 
According to the mechanism of action, antitranspirants can be divided into three categories. The first category includes preparations forming a vapour-impermeable film on the leaf surface (di-1-p-menthene belongs to this group, among others). The second category includes reflective preparations, which reflect part of solar radiation falling on the upper leaf surface (e.g. kaolin spraying), while the third category consists of preparations causing the closing of stomata (by influencing metabolic processes in plant tissues) [Moftah and Al-Humaid, 2005a, 2005b].

Di-1-p-menthene (pinolene) is a natural terpene polymer obtained from plant resin, which is used as a foliar antitranspirant in a form of water emulsion. It forms a thin film on leaves, which polymerises under the influence of sunlight, reaching high resistance and elasticity. It is a safe substance for the environment [Moftah and AlHumaid, 2005; Francini et al., 2011; Ouerghi et al., 2014].

The aim of the research was to assess the influence of di-1-p-menthene on gas exchange and water balance parameters and on the content of assimilation pigments in strawberry leaves at four measurement dates.

\section{MATERIAL AND METHODS}

In 2009-2010, a two-factor pot experiment in a completely randomized system was carried out in four replications in the vegetation hall of the West Pomeranian University of Technology in Szczecin. The object of the study was the strawberry cv. 'Salsa'. The first experimental factor included spraying the plants with an antitranspirant containing di-1-p-menthene (96\%) with the commercial name of Vapor Gard (Miller Chemical and Fertiliser Corporation, USA) at a concentration of $0.75 \%$. The antitranspirant was used once before flowering. The date of measurement of physiological parameters (strawberry development stage) was the second factor. The measurements were performed four times: before flowering (1st measurement date) - 7 days after the application of the antitranspirant, when the plants were in full flowering (2nd measurement date), in the middle of the harvest season (3rd measurement date) and fourteen days after the end of the harvest season (4th measurement date). Pots of $10 \mathrm{dm}^{3}$ capacity were filled with 8 $\mathrm{dm}^{3}$ of soil material. For all plants, the same min- eral fertilization was used. The doses of fertilization were $\left(\mathrm{kg} \cdot \mathrm{ha}^{-1}\right): 50 \mathrm{~N}, 80 \mathrm{P}$ and $100 \mathrm{~K}$. Potassium, phosphorus and half a dose of nitrogen fertilization was applied prior to planting. Half a dose of nitrogen was used before the flowering of the plants. In mid-April 2009, "frigo" plants were placed in containers, 1 piece per pot. The plants wintered in pots in an unheated greenhouse. Soil moisture was measured by means of soil contact tensiometers. All plants were watered when the tensiometer showed $450 \mathrm{hPa}$. Then plants were watered with $0.5 \mathrm{dm}^{3} \mathrm{H}_{2} \mathrm{O} /$ pot. All measurements of physiological parameters were performed on healthy, fully grown leaves in ten repetitions.

Gas exchange parameters measured in leaf tissues included $\mathrm{CO}_{2}$ assimilation intensity (A) and transpiration (E), stomatal conductance to water $\left(\mathrm{g}_{\mathrm{S}}\right)$ and substomatal $\mathrm{CO}_{2}$ concentration $\left(\mathrm{c}_{\mathrm{i}}\right)$. They were performed using a portable gas analyzer TPS-2, PP Systems, operating in an open system and equipped with a measuring chamber PLC4. The analyzer cuvette conditions were set to a constant supply of carbon dioxide at a concentration of $370 \mathrm{ppm}\left(\mu \mathrm{mol} \mathrm{CO} \cdot \mathrm{mol}^{-1}\right.$ air$)$, humidity equal to ambient humidity and lighting equal to 2053 PAR $\left(\mu \mathrm{mol} \cdot \mathrm{m}^{-2} \cdot \mathrm{s}^{-1}\right)$, provided by a light unit coming with the cuvette. The data describing assimilation intensity and transpiration were used to calculate photosynthetic water use efficiency (WUE), determined as the ratio of assimilation to transpiration rate. On the basis of the quotient of photosynthesis to stomatal conductance, the instantaneous photosynthetic index of water use efficiency (WUEI) was calculated.

Assimilation pigments content was determined in the same leaves, in which the gas exchange parameters were assessed. Chlorophyll content was measured using a method described by Arnon et al. [1956] and modified by Lichtenthaler and Wellburn [1983], and carotenoids content was assessed according to Hager and Mayer-Berthenrath [1966]. For the estimation of assimilation pigments content, a known mass of leaf (about $0.05 \mathrm{~g}$ ) were homogenized in 10 $\mathrm{cm}^{3}$ of $80 \%$ acetone. The homogenate was centrifuged at $2500 \mathrm{~g}$ for 10 minutes. The absorbance of the acetone extracts was measured at 440, 645 and $663 \mathrm{~nm}$ using a spectrophotometer (Marcel Mini). Relative water content (RWC) index in strawberry leaves was calculated as described by Yamasaki and Dillenburg [1999]. Leaf material was weighed to determine fresh weight and placed in distilled water for $24 \mathrm{~h}$ and then turgid 
weight was recorded. Finally, the samples were dried in an oven at $80^{\circ} \mathrm{C}$ for $48 \mathrm{~h}$ and the dry weights were recorded. RWC was calculated as: RWC $=[($ Fresh weight - Dry weight $) /($ Turgid weight-Dry weight) $] \times 100$.

The synthesis of the results from a two-year period was prepared. The obtained results were analysed with two-factor analysis of variance. In order to determine the significance of differences between mean values, Duncan confidence halfintervals were calculated at a significance level of $\mathrm{p}=0.05$. Statistical calculations were carried out using Statistica 10 software.

\section{RESULTS AND DISCUSSION}

The averaged research results on gas exchanged in the strawberry, which were obtained four times during the vegetative season, are presented in Table 1. Statistical analysis performed for the main effects did not show the influence of the antitranspirant used on gas exchange parameters, such as the net $\mathrm{CO}_{2}$ assimilation intensity, $\mathrm{H}_{2} \mathrm{O}$ stomatal conductance and substomatal $\mathrm{CO}_{2}$ concentration. According to Moftah and $\mathrm{Al}-\mathrm{Hu}-$ maid [2005a, 2005b], $\mathrm{H}_{2} \mathrm{O}$ stomatal conductance is a parameter with a value in polianthes (Polianthes tuberosa L.) increased under the influence of the application of the Vapor Gard preparation under soil drought conditions. In the research by Francini and Lorenzini [2011], the same antitranspirant did not modify the substomatal $\mathrm{CO}_{2}$ concentration in bean leaves. Antitranspirants are chemical compounds used to limit the transpiration process and to keep advantageous parameters of the water balance of plants [Song et al. 2011]. It was found that the application of the Vapor Gard preparation reduced the intensity of strawberry transpiration on average by $24.4 \%$. Ouerghi et al. obtained similar results [2014] in wheat and barley cultivated under drought conditions. These authors showed that the Vapor Gard antitranspirant decreases the intensity of transpiration and reduced the activity of the $\mathrm{CO}_{2}$ assimilation at the same time. Del Amor and Rubio [2009] showed a decrease in the intensity of net $\mathrm{CO}_{2}$ assimilation in peppers under the influence of the application of the Vapor Gard preparation by $10 \%$ as regards the control. Similarly, according to Francini and Lorenzini [2011], the Vapor Gard preparation reduced the intensity of transpiration at the simultaneous $\mathrm{CO}_{2}$ assimilation under ozone stress conditions.

Table 1. Effect of antitranspirant and measurement date on the parameters of gas exchange in the leaves of strawberry cv. 'Salsa'

\begin{tabular}{|c|c|c|c|c|c|}
\hline \multirow{2}{*}{ Parameter } & \multicolumn{4}{|c|}{ Measurement date ${ }^{2}$} & \multirow{2}{*}{ Mean } \\
\hline & I & II & III & IV & \\
\hline \multicolumn{6}{|c|}{$\mathrm{A}^{3}\left[\mu \mathrm{mol} \cdot \mathrm{m}^{-2} \cdot \mathrm{s}^{-1}\right]$} \\
\hline $\mathrm{C}^{1}$ & $7.105 a^{4}$ & $9.392 \mathrm{~b}$ & $10.445 \mathrm{~b}$ & $9.343 \mathrm{~b}$ & $9.071 \mathrm{a}$ \\
\hline AT & 9.675 b & $7.475 \mathrm{a}$ & $9.355 \mathrm{~b}$ & $9.203 \mathrm{~b}$ & $8.927 \mathrm{a}$ \\
\hline Mean & $8.390 \mathrm{a}$ & $8.434 \mathrm{a}$ & $9.900 \mathrm{~b}$ & $9.273 \mathrm{ab}$ & \\
\hline \multicolumn{6}{|c|}{$\mathrm{E}\left[\mathrm{mmol} \cdot \mathrm{m}^{-2} \cdot \mathrm{s}^{-1}\right]$} \\
\hline C & $1.963 \mathrm{~b}$ & $1.540 \mathrm{ab}$ & $2.120 \mathrm{~b}$ & $2.890 \mathrm{c}$ & $2.128 \mathrm{~b}$ \\
\hline AT & $1.683 \mathrm{~b}$ & $0.948 \mathrm{a}$ & $1.770 \mathrm{~b}$ & $2.030 \mathrm{~b}$ & $1.608 \mathrm{a}$ \\
\hline Mean & $1.823 \mathrm{~b}$ & $1.244 \mathrm{a}$ & $1.945 b$ & $2.460 \mathrm{c}$ & \\
\hline \multicolumn{6}{|c|}{$\mathrm{C}_{\mathrm{i}}\left[\mu \mathrm{mol} \cdot \mathrm{mol}^{-1}\right]$} \\
\hline $\mathrm{C}$ & 247.9 a & $259.7 \mathrm{ab}$ & $317.2 \mathrm{c}$ & 305.7 c & $282.6 \mathrm{a}$ \\
\hline AT & 299.8 bc & $220.2 \mathrm{a}$ & $252.8 \mathrm{a}$ & 299.8 bc & $268.1 \mathrm{a}$ \\
\hline Mean & $273.9 \mathrm{ab}$ & $240.0 \mathrm{a}$ & $285.0 \mathrm{~b}$ & 302.7 b & \\
\hline \multicolumn{6}{|c|}{$\mathrm{g}_{\mathrm{s}}\left[\mathrm{mmol} \cdot \mathrm{m}^{-2} \cdot \mathrm{s}^{-1}\right]$} \\
\hline $\mathrm{C}$ & 185.6 a & $151.0 \mathrm{a}$ & 195.3 a & $286.7 \mathrm{~b}$ & $204.7 \mathrm{a}$ \\
\hline AT & $185.8 \mathrm{a}$ & $176.8 \mathrm{a}$ & 200.9 a & $284.4 \mathrm{~b}$ & $212.0 \mathrm{a}$ \\
\hline Mean & $185.7 a b$ & 163.9 a & $198.1 \mathrm{~b}$ & 285.6 c & \\
\hline
\end{tabular}

${ }^{1} \mathrm{C}$ - control, AT - antitranspirant, ${ }^{2} \mathrm{I}$ - before flowering, II - full flowering, III - middle of the harvest season, $\mathrm{IV}$ - after the end of the harvest season, ${ }^{3} \mathrm{~A}-$ assimilation $\mathrm{CO}_{2}, \mathrm{E}-$ transpiration, $\mathrm{c}_{\mathrm{i}}-$ concentration of carbon dioxide in the intercellular spaces, $\mathrm{g}_{\mathrm{S}}$ - stomal conductance for water.

${ }^{4}$ Means assigned identical letters do not differ significantly at the level of significance $\alpha=0.05$. 
Table 2. Effect of antitranspirant and measurement date on mean values of photosynthetic index of water use efficiency (WUE) and instantaneous photosynthetic index of water use efficiency (WUEI) in the leaves of strawberry cv. 'Salsa'

\begin{tabular}{|c|c|c|c|c|c|}
\hline \multirow{2}{*}{ Parameter } & \multicolumn{4}{|c|}{ Measurement date $^{2}$} & \multirow{2}{*}{ Mean } \\
\hline & I & II & III & IV & \\
\hline \multicolumn{6}{|c|}{ WUE $\left[\mu \mathrm{mol} \mathrm{CO} \cdot \mathrm{mmol} \mathrm{H}_{2} \mathrm{O}^{-1}\right]$} \\
\hline $\mathrm{C}^{1}$ & $3.62 a b^{3}$ & $6.10 \mathrm{~cd}$ & $4.93 \mathrm{abc}$ & $3.23 \mathrm{a}$ & $4.47 \mathrm{a}$ \\
\hline AT & $5.75 \mathrm{bc}$ & $7.89 \mathrm{~d}$ & $5.29 a b c$ & $4.53 \mathrm{abc}$ & $5.87 \mathrm{~b}$ \\
\hline Mean & $4.69 a$ & $6.99 \mathrm{~b}$ & $5.11 \mathrm{a}$ & $3.88 \mathrm{a}$ & \\
\hline \multicolumn{6}{|c|}{ WUEl $\left[\mu \mathrm{mol} \mathrm{CO}_{2} \cdot \mathrm{mmol} \mathrm{H}_{2} \mathrm{O}^{-1}\right]$} \\
\hline C & $0.038 \mathrm{ab}$ & $0.062 \mathrm{c}$ & $0.054 \mathrm{bc}$ & 0.033 a & $0.047 a$ \\
\hline AT & $0.052 \mathrm{bc}$ & $0.042 \mathrm{ab}$ & $0.047 \mathrm{ab}$ & $0.032 \mathrm{a}$ & $0.043 \mathrm{a}$ \\
\hline Mean & $0.045 \mathrm{~b}$ & $0.052 \mathrm{~b}$ & $0.050 \mathrm{~b}$ & $0.033 a$ & \\
\hline
\end{tabular}

${ }^{1} \mathrm{C}$ - control, AT - antitranspirant, ${ }^{2} \mathrm{I}$ - before flowering, II - full flowering, III - middle of the harvest season, IV - after the end of the harvest season,

${ }^{3}$ Means assigned identical letters do not differ significantly at the level of significance $\alpha=0.05$.

By comparing the average activity of gas intensity at individual developmental stages of the analysed strawberry cultivar, it can be concluded that the greatest net assimilation and transpiration were shown in strawberries on the 3rd measurement date (harvest season) and it differed significantly from the intensity of these processes on the 1 st and 2 nd dates. The flowering strawberry plants were characterised by the lowest intensity of transpiration. The greatest substomatal $\mathrm{CO}_{2}$ concentration was found on the $3 \mathrm{rd}$ and 4 th measurement dates - it was significantly different from the concentration found at the 2 nd date. For the stomatal $\mathrm{H}_{2} \mathrm{O}$ conductance, its highest value was observed after the harvest season (Table 1).

An analysis of the interactions between experimental factors revealed that for the net assimilation, its values were found in leaves, which were not treated with the antitranspirant on the 1st measurement date and on the 2nd measurement date after the antitranspirant application (Table 1). In the other experimental combinations, the net assimilation concentration remained at a similar level. Experimental plants on the 4th measurement date were characterised by the highest intensity of transpiration. Substomatal $\mathrm{CO}_{2}$ concentration showed considerable variability, depending on both the antitranspirant action and the developmental stage of the analysed species. For stomatal $\mathrm{H}_{2} \mathrm{O}$ conductance, its highest values were found in control plants and plants treated with the Vapor Gard preparation after the harvest season.

According to Jeżowski et al. [2009] and Wróbel and Wróbel [2015], the photosynthetic index of water use efficiency (WUE) is mostly determined by environmental conditions of the plant growth, while the instantaneous photosynthetic index of water use efficiency (WUEI) mostly depends on the plant genotype. Table 2 presents the average value of photosynthetic water use indices in photosynthesis at individual developmental stages of the analysed strawberry cultivar under the influence of antitranspirant treatment. On the basis of the results obtained, it can be found that the application of the Vapor Gard preparation increased the photosynthetic index of water use efficiency (WUE) and it did not influence the value of the WUEI index. The highest value of the WUE index was shown in flowering strawberry plants. At the other measurement dates, its values were lower and similar. The WUEI index remained at the same level at the stages before flowering, during flowering and during the harvest season of strawberry, while it was the lowest after harvest season. According to Moftah and AlHumaid [2005], the Vapor Gard preparation increased the WUE index in Polianthes tuberosa L. under water stress conditions, while in research by Francini and Lorenzini [2011], this preparation also increased the WUEI value in bean plants under ozone stress conditions.

The average values of assimilation pigments, i.e. chlorophyll "a", "b", total chlorophyll (chlorophyll " $\mathrm{a}+\mathrm{b}$ ") and carotenoids, are presented in Table 3. On the basis of the results obtained, it was found that the application of the antitranspirant did not influence the content of all determined pigments in leaves of the analysed species or the ratio of chlorophyll "a" to "b". Similar results 
Table 3. Effect of antitranspirant and measurement date on content of assimilation pigments in leaves of strawberry cv. 'Salsa'

\begin{tabular}{|c|c|c|c|c|c|}
\hline \multirow{2}{*}{ Parameter } & \multicolumn{4}{|c|}{ Measurement date ${ }^{2}$} & \multirow{2}{*}{ Mean } \\
\hline & 1 & II & III & IV & \\
\hline \multicolumn{6}{|c|}{ Chlorophyll a $\left[\mathrm{mg} \cdot \mathrm{g}^{-1} \mathrm{FW}\right]$} \\
\hline $\mathrm{C}^{1}$ & $1.462 \mathrm{de}^{3}$ & 1.296 cde & $0.970 a b$ & $0.991 \mathrm{ab}$ & $1.180 \mathrm{a}$ \\
\hline AT & $1.433 \mathrm{de}$ & $1.255 \mathrm{~cd}$ & $1.112 \mathrm{bc}$ & $0.812 \mathrm{a}$ & $1.153 \mathrm{a}$ \\
\hline Mean & $1.448 \mathrm{~d}$ & $1.276 \mathrm{c}$ & $1.041 \mathrm{~b}$ & $0.901 \mathrm{a}$ & \\
\hline \multicolumn{6}{|c|}{ Chlorophyll b $\left[\mathrm{mg} \cdot \mathrm{g}^{-1} \mathrm{FW}\right]$} \\
\hline C & $0.542 \mathrm{~d}$ & $0.495 \mathrm{~cd}$ & $0.412 b$ & $0.390 \mathrm{~b}$ & $0.560 \mathrm{a}$ \\
\hline AT & $0.531 \mathrm{~d}$ & $0.488 \mathrm{~cd}$ & $0.435 \mathrm{bc}$ & $0.315 a$ & $0.443 a$ \\
\hline mean & $0.536 \mathrm{c}$ & $0.492 \mathrm{c}$ & $0.424 \mathrm{~b}$ & $0.353 \mathrm{a}$ & \\
\hline \multicolumn{6}{|c|}{ Chlorophyll $\mathrm{a}+\mathrm{b}\left[\mathrm{mg} \cdot \mathrm{g}^{-1} \mathrm{FW}\right]$} \\
\hline C & $2.004 d$ & $1.791 \mathrm{~cd}$ & $1.382 \mathrm{ab}$ & $1.380 \mathrm{ab}$ & $1.640 \mathrm{a}$ \\
\hline AT & $1.964 \mathrm{~d}$ & $1.744 \mathrm{~cd}$ & $1.548 \mathrm{bc}$ & $1.127 \mathrm{a}$ & $1.595 \mathrm{a}$ \\
\hline Mean & $1.984 \mathrm{~d}$ & $1.767 \mathrm{c}$ & $1.465 b$ & $1.254 \mathrm{a}$ & \\
\hline \multicolumn{6}{|c|}{ Chlorophyll a/b } \\
\hline C & $2.70 \mathrm{~b}$ & $2.62 \mathrm{~b}$ & $2.35 \mathrm{a}$ & $2.54 \mathrm{~b}$ & $2.55 \mathrm{a}$ \\
\hline AT & $2.70 \mathrm{~b}$ & $2.57 \mathrm{~b}$ & $2.56 \mathrm{~b}$ & $2.58 \mathrm{~b}$ & $2.60 \mathrm{a}$ \\
\hline Mean & $2.70 \mathrm{c}$ & $2.59 \mathrm{bc}$ & $2.46 \mathrm{a}$ & $2.56 a b$ & \\
\hline \multicolumn{6}{|c|}{ Carotenoids $\left[\mathrm{mg} \cdot \mathrm{g}^{-1} \mathrm{FW}\right]$} \\
\hline $\mathrm{C}$ & $0.872 \mathrm{c}$ & $0.816 \mathrm{c}$ & $0.596 a b$ & $0.585 a b$ & $0.717 \mathrm{a}$ \\
\hline AT & $0.830 \mathrm{c}$ & $0.776 \mathrm{c}$ & 0.487 a & $0.618 b$ & $0.678 a$ \\
\hline Mean & $0.851 \mathrm{~b}$ & $0.796 \mathrm{~b}$ & $0.541 \mathrm{a}$ & 0.602 a & \\
\hline
\end{tabular}

${ }^{1} \mathrm{C}$ - control, AT - antitranspirant, ${ }^{2} \mathrm{I}$ - before flowering, II - full flowering, III - middle of the harvest season, IV - after the end of the harvest season,

${ }^{3}$ Means assigned identical letters do not differ significantly at the level of significance $\alpha=0.05$.

were also obtained by Moftah and Al-Humaid [2005a, 2005b] for Polianthes tuberosa L., Francini and Lorenzini [2011] for bean plants and Abdel - Fattah [2013] for Hibiscus rosa - sinensis L. The highest content of chlorophyll "a" and total chlorophyll was found at the first measurement date (before flowering), these values decreased with each subsequent developmental stage of the strawberry plants. The analysis of the influence of the Vapor Gard preparation on the assimilation pigment content at various developmental stages of strawberry plants shows that for chlorophyll "a", total chlorophyll and carotenoids, the antitranspirant used did not influence their content at any of the measurement dates. For chlorophyll "b", such a relationship was shown at all developmental stages of strawberry plants, apart from 4th measurement dates (after the end of the harvest season), during which the use of the Vapor Gard preparation reduced the content of this pigment in the leaves. The application of the Vapor Gard preparation increased the ratio of chlorophyll "a" to chlorophyll "b" at the harvest season of strawberry fruits. Research on the influence of the Vapor Gard antitranspirant on the content of assimilation pigments in leaves of hardy kiwi plants at four times during the vegetative season was conducted by Latocha et al. [2009]. These authors observed an increase in the chlorophyll content in the leaves of the tested species under the influence of antitranspirant application only at the beginning of the vegetative season.

The relative water content index (RWC) is considered one of the most important parameters used for the assessment of plant water balance. According to Tezary et al. [2002], the value of this index is positively correlated with the photosynthetic efficiency of plants. The modification of the water balance is a commonly registered response of plants to various environmental factors. According to Abdel-Fattah [2013], antitranspirants, which form a film on the surface of the plants, increase the relative water content in leaves. The antitranspirant used increased the relative water content in leaves of the tested strawberry cultivar by $4.4 \%$ (Table 4 ). The value of the 
Table 4. Effect of antitranspirant and measurement date on RWC in the leaves of strawberry cv. 'Salsa'

\begin{tabular}{|c|c|c|c|c|c|}
\hline \multirow{2}{*}{ Parameter } & \multicolumn{4}{|c|}{ Measurement date ${ }^{2}$} & \multirow{2}{*}{ Mean } \\
\hline & 1 & II & III & IV & \\
\hline \multicolumn{6}{|c|}{ RWC [\%] } \\
\hline $\mathrm{C}^{1}$ & $84.12 b^{3}$ & 77.98 a & $90.03 \mathrm{~cd}$ & $86.29 \mathrm{bc}$ & $84.61 \mathrm{a}$ \\
\hline AT & $88.71 \mathrm{c}$ & $83.27 \mathrm{~b}$ & $93.12 \mathrm{~d}$ & $88.22 \mathrm{c}$ & $88.33 \mathrm{~b}$ \\
\hline Mean & $86.41 \mathrm{~b}$ & $80.62 \mathrm{a}$ & 91.57 c & $87.26 \mathrm{~b}$ & \\
\hline
\end{tabular}

${ }^{1} \mathrm{C}$ - control, AT-antitranspirant, ${ }^{2} \mathrm{I}$ - before flowering, II - full flowering, III - middle of the harvest season, IV - after the end of the harvest season.

${ }^{3}$ Means assigned identical letters do not differ significantly at the level of significance $\alpha=0.05$.

RWC index also depended on the developmental stage of strawberry plants. The highest relative water content was shown in leaves of the tested strawberry cultivar on the 3rd measurement date $(91.57 \%)$, while the lowest is on the 2nd stage $(80.62 \%)$. It can be concluded on the basis of the analysis of the interactions between experimental factors that values higher than the RWC factor were found in antitranspirant-treated plants than in control plants on the 1st and 2nd measurement dates. During the harvest season and after its end, the relative water content in plant leaves sprayed with the Vapor Gard preparation and in control plants remained at a similar level.

\section{CONCLUSIONS}

Foliar application of the Vapor Gard antitranspirant decreases the intensity of strawberry transpiration without changing the $\mathrm{CO}_{2}$ assimilation activity. Plants sprayed with the tested preparation were characterised by a higher relative water content (RWC) in leaves and a higher value of the photosynthetic index of water use efficiency (WUE). The antitranspirant did not influence the content of assimilation pigments in strawberry leaves. The values of the determined physiological features depended on the measurement date (developmental stage) of the tested strawberry cultivar.

\section{REFERENCES}

1. Abdel-Fattah G.H. 2013. Response of waterstressed rose of China (Hibiscus rosa-sinensis L.) plant to treatment with calcium carbonate and vapor gard antitranspirants. J. Appl. Sci. Res., 9(6), 3566-3572.

2. Arnon D.J., Allen M.B., Whatley F., 1956. Photosynthesis by isolated chloroplast. Biochim. Biphys.
Acta 20, 449-461.

3. Del Amor F.M., Rubio J.S. 2009. Effects of antitranspirant spray and potassium: calcium: magnesium ratio on photosynthesis, nutrient and water uptake, growth, and yield of sweet pepper. Journal of Plant Nutrition, 32, 97-111.

4. Francini A., Lorenzini G., Nali C. 2011. The antitranspirant di-1-p-menthene, a potential chemical protectant of ozone damage to plants. Water Air Soil Pollut. 219, 459-472.

5. Hager A., Mayer-Berthenrath T., 1966. Die Isolierung und quanttaive Bestimung der Carotenoide und Chlorophyll von Blatern, Algen und isolierten Chloroplasten mit Hilfe Dunnschichtchromatographischer Methoden. Planta. Berlin 69, 198-217.

6. Jeżowski S., Głowacka K., Kaczmarek Z. 2009. Wstępna ocena głównych parametrów wymiany gazowej związanych $\mathrm{z}$ fotosyntezą $\mathrm{w}$ odniesieniu do plonowania traw energetycznych z rodzaju $\mathrm{Mi}$ scanthus w pierwszym roku uprawy. Acta Agrophysica, 14(1), 73-81.

7. Klamkowski K., Treder W., Tryngiel-Gać A. 2006. The effects of substrate moisture content on water potential, gas exchange rates, growth, and yield in strawberry plants grown under greenhouse conditions. J. Fruit Ornam. Plant Res. 14, 163-171.

8. Klamkowski K., Treder W. 2006. Morphological and physiological responses of strawberry plants to water stress. Agriculturae Conspectus Scientificus 71(4), 159-165.

9. Klamkowski K., Treder W. 2008. Response to drought stress of three strawberry cultivars grown under greenhouse conditions. J. Fruit Ornam. Plant Res. 16, 179-188.

10. Latocha P., Ciechocińska M., Pietkiewicz S., Kalaji M. K. 2009. Preliminary assessment of antitranspirant Vapor Gard influence on Actinidia arguta growing under drought stress conditions. Ann. Warsaw Univ. Life Sc. 30, 149-150.

11. Lichtenthaler H.K., Wellburn A.R., 1983. Determinations of total carotenoids and chlorophyll $\mathrm{a}$ and $\mathrm{b}$ of leaf extracts in different solvents. Biochem. Soc. Trans. 11, 591-592. 
12. Masoud A.A.B. 2012. Impact of some antitranspirants on yield and fruit quality of hamawy apricot trees grown in sandy soils. Res. J. Agric. \& Biol. Sci., 8(2), 78-82,

13. Moftah A.E., Al-Humaid A.I. 2005a. Effects of kaolin and pinolene film-forming polymers on water relations and photosynthetic rate of tuberose ( $\mathrm{Po}$ lianthes tuberosa L.). J. King Saud Univ., Vol. 18, Agric. Sci., (1), 35-49.

14. Moftah A.E., Al-Humaid A.I. 2005b. Effects of antitranspirants on water relations and photosynthetic rate of cultivated tropical plant (Polianthes tuberosa L.). Pol. J. Ecol. 53(2), 165-175.

15. Ouerghi F., Ben-Hammouda M., Teixeira Da Silva J.A., Albouchi A., Bouzaien G., Aloui S., CheikhM'Hamed H., Nasraoui B. 2014. The effects of Vapor Gard on some physiological traits of durum wheat and barley leaves under water stress. Agric.
Conspec. Sci. 79(4), 261-267.

16. Song X.W., Wang C., Zhang Q., Li Y. 2011. Postharvest physio-chemical responses of cut rose (Rosa hybrida L.) to antitranspirant and vacuum cooling. Philipp. Agric. Scientist., 94(4), 368-374.

17. Tezara W., Mitchell V., Driscoll S.P., Lawrol D.W. 2002. Effects of water deficit and its interaction with $\mathrm{CO}_{2}$ supply on the biochemistry and physiology of photosynthesis in sunflower. J. Exp.Bot. 375, 1781-1791.

18. Wróbel J., Wróbel M. 2015. Porównanie parametrów aktywności wymiany gazowej oraz plonu trzech odmian wierzby wiciowej (Salix viminalis L.) pochodzących $\mathrm{z}$ wieloletniej plantacji. Acta Agrophysica. 22(2), 219-231.

19. Yamasaki S., Dillenburg L.R., 1999. Measurements of leaf relative water content in Araucaria angustifolia. Rev. Bras. Fisiol. Vegetal. 11(2), 69-75. 